\title{
A new modified-serpentine flow field for application in high temperature polymer electrolyte fuel cell
}

Debanand Singdeo $^{\mathrm{a}, \mathrm{b}}$, Tapobrata Dey ${ }^{\mathrm{a}}$, Shrihari Gaikwad ${ }^{\mathrm{a}}$, Søren Juhl Andreasen ${ }^{\mathrm{b}}$, Prakash C Ghosh $^{\mathrm{a}^{*}}$

${ }^{a}$ Department of Energy Science and Engineering Indian Institute of Technology Bombay

Mumbai-400076

India

Ph.: +912225767896

Fax: +912225764890

Email:pcghosh@iitb.ac.in

${ }^{b}$ Department of Energy Technology

Aalborg University

Pontoppidanstraede 101

Denmark

*Corresponding author 


\begin{abstract}
Flow field design for the distribution of reactants and products on the electrode surface plays an important role in the overall performance of the fuel cell. It acts as a crucial factor when the laboratory scale fuel cell is scaled up for commercial applications. In the present work, a novel flow field design is proposed and its usefulness for the fuel cell applications are evaluated in a high-temperature polymer electrolyte fuel cell. The proposed geometry retains some of the features of serpentine flow field such as multiple bends, while modifications are made in its inplane flow path to achieve comparatively uniform reactant and product distribution. A threedimensional CFD model is developed to analyze the effectiveness of the proposed flow field. An HT-PEFC is fabricated and experimented with the proposed flow field for experimental validation. Furthermore, a low-cost current distribution mapping device is developed to validate the current density distribution on the electrode obtained from the CFD model. It exhibits a mismatch of $4 \%$ in the spatial distribution of current density between the modelling and experimental results. The proposed design is capable of achieving higher uniformity in current distribution across the active area (0.998 for modified serpentine and 0.96 serpentine) compared to serpentine flow field. This aids in boosting the current density of the cell by $27 \%$ at $0.57 \mathrm{~V}$ operations.
\end{abstract}

\title{
Keywords
}

High-temperature polymer electrolyte fuel cell; CFD modelling; flow field; current density distribution mapping 


\begin{tabular}{ll} 
Nomenclature \\
BPP & Bipolar Plate \\
CC & Current Collector \\
CDMD & Current Distribution Measurement Device \\
CFD & Computational Fluid Dynamics \\
CHP & Combined Heat and Power \\
CO & Carbon Monoxide \\
EIS & Electrochemical Impedance Spectroscopy \\
FEM & Finite Elements Method \\
FVM & Finite Volume Method \\
GDL & Gas Diffusion Layer \\
HT-PEFC & High-Temperature Polymer Electrolyte Fuel Cell \\
LT-PEFC & Low-Temperature Polymer Electrolyte Fuel Cell \\
MEA & Membrane Electrode Assembly \\
ORR & Oxygen Reduction Reaction \\
PBI & Poly-benzimidazole \\
PCB & Printed Circuit Board \\
PEFC & Polymer Electrolyte Fuel Cell \\
SIMPLE & Semi-Implicit Method for Pressure Linked Equations \\
RAM & Random Access Memory \\
UDF & User Defined Functions \\
UI & Uniformity Index \\
\hline HE &
\end{tabular}




\section{Symbols}

\begin{tabular}{|c|c|}
\hline$\alpha$ & Permeability, $\mathrm{m}^{2}$ \\
\hline$\alpha_{\mathrm{k}}$ & Charge transfer co-efficient \\
\hline $\mathrm{A}_{\text {electrode }}$ & Active area, $\mathrm{m}^{2}$ \\
\hline$A_{\text {seg }}$ & Area of each segment of CDMD, $\mathrm{m}^{2}$ \\
\hline $\mathrm{C}_{\mathrm{p}}$ & Specific heat, $\mathrm{J} \mathrm{kg}^{-1}, \mathrm{~K}^{-1}$ \\
\hline $\mathrm{C}_{\mathrm{O}_{2}}^{\mathrm{ref}}$ & Reference concentration of oxygen, $\mathrm{mol} \mathrm{m}^{-3}$ \\
\hline $\mathrm{C}_{\mathrm{O}_{2}}$ & Local concentration of oxygen $\mathrm{mol} \mathrm{m}^{-3}$ \\
\hline$D_{i}$ & Binary diffusivity, $\mathrm{m}^{2} \mathrm{~s}^{-1}$ \\
\hline $\mathrm{D}_{\mathrm{i}}{ }^{\text {eff }}$ & Effective diffusivity, $\mathrm{m}^{2} \mathrm{~s}^{-1}$ \\
\hline $\mathrm{E}_{\mathrm{A}}$ & Activation energy, $\mathrm{J} \mathrm{mol}^{-1}$ \\
\hline$\epsilon$ & Porosity \\
\hline $\mathrm{F}$ & Faraday constant, $\mathrm{C} \mathrm{kmol}^{-1}$ \\
\hline$J_{c}$ & Local current density, $\mathrm{A} \mathrm{m}^{-2}$ \\
\hline $\mathrm{J}_{\mathrm{i}}$ & Diffusive flux of $i^{\text {th }}$ reactant \\
\hline $\mathrm{J}_{\mathrm{c}, \mathrm{T}}$ & Reference current density at cathode at at temperature $\mathrm{T}, \mathrm{A} \mathrm{m}^{-2}$ \\
\hline $\mathrm{J}_{0, \mathrm{ref}}$ & Reference current density at reference temperature, $\mathrm{A} \mathrm{m}^{-2}$ \\
\hline $\mathrm{J}_{\mathrm{C}, \mathrm{avg}}$ & Average current density over the active area, $\mathrm{A} \mathrm{m}^{-2}$ \\
\hline $\mathrm{J}_{\mathrm{C}}^{\mathrm{k}}$ & Current density measured on k-th segment of CDMD, $\mathrm{A} \mathrm{m}^{-2}$ \\
\hline$J_{V}$ & Volumetric current density, $\mathrm{A} \mathrm{m}^{-3}$ \\
\hline $\mathrm{k}_{\text {eff }}$ & Effective thermal conductivity, $\mathrm{J} \mathrm{s}^{-1} \mathrm{~m}^{-1} \mathrm{~K}^{-1}$ \\
\hline$\lambda$ & Stoichiometry co-efficient \\
\hline$\dot{\mathrm{m}}$ & Mass flow rate, $\mathrm{kg} \mathrm{s}^{-1}$ \\
\hline
\end{tabular}




\begin{tabular}{|c|c|}
\hline $\mathrm{M}_{\mathrm{i}}$ & Molecular weight of $\mathrm{i}^{\text {th }}$ species, $\mathrm{kg} \mathrm{kmol}^{-1}$ \\
\hline $\mathrm{MW}_{\mathrm{O}_{2}}$ & Molecular weight of oxygen, $\mathrm{kg} \mathrm{kmol}^{-1}$ \\
\hline$\eta_{\text {act, }, \mathrm{c}}$ & Cathode local activation overpotential, V \\
\hline $\mathrm{n}$ & Number of electrons per mole of reactant, $\mathrm{mol}^{-1}$ \\
\hline$P$ & Pressure, $\mathrm{Pa}$ \\
\hline $\mathrm{R}$ & Real gas constant $\mathrm{J} \mathrm{K}^{-1} \mathrm{~mol}^{-1}$ \\
\hline $\mathrm{R}_{\text {tot }}$ & Total internal area specific electrical resistance, $\Omega \mathrm{m}^{2}$ \\
\hline $\mathrm{R}_{\mathrm{mem}}$ & Area specific resistance of membrane \\
\hline $\mathrm{R}_{\text {con }}(\mathrm{T})$ & Area specific contact resistance, $\Omega \mathrm{m}^{2}$ \\
\hline $\mathrm{R}_{\mathrm{CDM}}(\mathrm{T})$ & Area-specific resistance of CDMD, $\Omega \mathrm{m}^{2}$ \\
\hline$\rho$ & Density, $\mathrm{kg} \mathrm{m}^{-3}$ \\
\hline $\mathrm{S}_{\mathrm{i}}$ & Species source term, $\mathrm{kg} \mathrm{m}^{-3} \mathrm{~s}^{-1}$ \\
\hline $\mathrm{S}_{\mathrm{T}}$ & Energy source term, $\mathrm{J} \mathrm{m}^{-3} \mathrm{~s}^{-1}$ \\
\hline$\Delta \mathrm{S}$ & Entropy change, $\mathrm{J} \mathrm{K}^{-1}$ \\
\hline $\mathrm{T}$ & Temperature, $\mathrm{K}$ \\
\hline $\mathrm{T}_{\text {ref }}$ & Reference temperature, $\mathrm{K}$ \\
\hline$t_{\text {con }}$ & Interfacial separation at the planes engaged at the contact, $\mathrm{m}$ \\
\hline$t_{\text {electrode }}$ & Thickness of the electrode, $\mathrm{m}$ \\
\hline$t_{\mathrm{mem}}$ & Thickness of the membrane, $\mathrm{m}$ \\
\hline$\overline{\mathrm{u}}$ & Velocity, $\mathrm{m} \mathrm{s}^{-1}$ \\
\hline$\mu$ & Viscosity, $\mathrm{Pa} \mathrm{s}$ \\
\hline $\mathrm{V}_{\mathrm{OC}}$ & Open circuit voltage, $\mathrm{V}$ \\
\hline $\mathrm{V}_{\mathrm{OP}}$ & Operating voltage, $\mathrm{V}$ \\
\hline
\end{tabular}


Species mass fraction 


\section{Introduction}

Fuel cells are considered as one of the potential future key technologies suitable for cleaner and efficient energy conversion. In the last two decades, a new generation of fuel cells called hightemperature polymer electrolyte fuel cell (HT-PEFC) has emerged as a subject of intensive research and development. The usage of phosphoric acid doped polybenzimidazole (PBI) membrane has been a highlight of this technology, allowing the elevation of the operating temperatures in the range $\sim 120-180{ }^{\circ} \mathrm{C}$. This leads to some distinct operational advantages, in comparison with the sulphonated membrane based electrolyte. Notable amongst them is the absence of complex water management issues, lower susceptibility to carbon monoxide (CO) poisoning, ease of thermal management and better electrochemical kinetics [1]. It has been reported by Krishnan et al. that these fuel cells can tolerate as much as $1 \mathrm{vol} \% \mathrm{CO}$ without sacrificing the performance at $210{ }^{\circ} \mathrm{C}[2,3]$. Due to its ability to tolerate higher $\mathrm{CO}$ in the fuel mixture, these fuel cells can be directly fed with reformed hydrogen by reforming hydrocarbons [4-7] eliminating precious metal catalyst based purifications. Furthermore, studies on these fuel cells have revealed that they can be operated in combined heat and power mode (CHP); reaching higher efficiencies $(\sim 87 \%)$ [8]. Even though the conversion efficiency of HT-PEM is slightly lower compared to LT-PEMFC, a reduced balance of plant leads to comparable overall efficiency values [9]. On the downside, there is a significant amount of time and energy involved in starting up these fuel cells from room temperature. Researchers have studied different methods in order to formulate a suitable warm up strategy for these fuel cells [10], [11]. The issue of phosphoric acid leaching and uptake in the porous bipolar plates over a period of time are important aspects which need attention to ensure longer durability [12]. The loss of acid from membrane electrode assembly (MEA) manifests in the form of a higher ohmic drop and increase in oxygen reduction overpotential in the cell performance characteristics [13]. At the catalyst 
layer, degradation due to agglomeration and sintering of the catalyst has also been reported by some researchers [14].

As of present, the reported flow fields which have been conceived for application in the field of fuel cells are numerous. Some of the options include serpentine, parallel, pin-type, integrated, spiral, bio-inspired and porous flow fields [15-19]. A particular geometry possesses a number of parameters such as channel width, depth, the shape of cross-section, the number of turns/channels, taper ratios, and path length [20-24]. These can be optimized as per the performance requirements. Other options include arranging reactant and oxidant distribution in these flow fields in co-flow or counter-flow mode. Computational Fluid Dynamics (CFD) can be used as a tool to identify the potential of different designs as evident from the numerous successful applications in LT-PEFCs [25-27]. Comparatively, fewer works based on CFD has been reported in the field of HT-PEFCs. Su et al. performed one of the earliest simulations on the performance of a PEFC above $100{ }^{\circ} \mathrm{C}$ using CFD, albeit the electrolyte was not phosphoric doped PBI [28]. To study the effect of cell temperature and porosity on the performance, a 2D single phase model was proposed by Sun et al. Their results show that gas diffusion layers (GDLs) possessing higher porosity can assist in improving performance [29]. A numerical model using finite element method (FEM) has been used by Thomas et al. to evaluate an open cathode flow field configuration. The cell design was found to reduce the overall stack volume and eliminate the requirement of a separate cooling manifold [30]. A 3D, steady state model for an HT-PEFC possessing phosphoric doped PBI membrane was put forward by Lobato et al [31]. Their aim was to compare the performance for serpentine, parallel and pin type geometries for a given cell area of $50 \mathrm{~cm}^{2}$. At larger cell sizes $\left(200 \mathrm{~cm}^{2}\right)$ and at stack level, CFD analysis has been reported by a research group at Forschungszentrum Juelich using the porous volume method 
[32-34]. The CFD study was instrumental in illustrating that the flow field design was more dominating than the heating strategy in the final local current density distribution. It can be noted that for HT-PEFCs, serpentine flow fields have been selected in a significant number of works, thus highlighting its importance. Krastev et al. also carried out CFD study of a serpentine flow field to investigate electrical and thermal performance [35]. Coupled FEM-CFD model of a unit cell has been reported by Chippar et al. to study the role of gasket deformation on current density inhomogeneity [36].

The significance of a CFD based study can be further augmented by supporting it with experimental data sets. In many studies, comparison with polarisation behaviour has been held as an acceptable form of validation. However, local measurement of current density stands as a better option. This is possible using the segmentation method, which involves gathering cell operating data such as voltage and current density from different cell zones by dividing one or more of the following components into a number of sub-sections: the BPP, GDL, and CC. This technique has been used to study performance homogeneity due to different reactant flow patterns by Alaefour et al. using PCB for segmentation [37]. A detailed discussion on various segmented studies on fuel cells can be found in [38].

The focus of the current work underlies in identifying and addressing some essential aspects relevant to performance and diagnostics of HT-PEFC. The first issue identified from literature is regarding the current density gradient that has been experimentally noted by Siegel et al. Their experiments based on sectional electrochemical impedance spectroscopy (EIS) have shown that serpentine design (type I) operating at a stoichiometry of 1.3(anode) and 1.4(cathode) exhibits high current density near the inlets by about $142.96 \%$ compared to the mean current density of 0.31 A cm-2 [39]. Simultaneously, the outlet region shows 50.09\% lower current density 
compared to the mean. Other variation of the serpentine flow field configurations (type II and III) shows similarity in the nature of the current density distribution, with a prominent role played by stoichiometry in dictating the (inlet to outlet) current density gradient. Yet, as serpentine flow field continues to be at the forefront of flow field choices in fuel cells for HTPEFCs, it's important to explore alternatives for enhanced performance.

A potential alternative to the serpentine design has been presented in this work for improved homogeneity in performance with respect to the serpentine design. Comparative evaluation of the flow field is carried out on the basis of local performance data, obtained using both numerical and experimental technique. The numerical model uses standard CFD procedures as a tool to simulate geometry of commercial scale HT-PEFC cell with reasonable computational resources. The model includes the interfacial contact resistance at the interface of the GDL and BPP, which is a function of stacking force. Its usefulness lies in the determination of local current density distribution across the cell active area at different operating voltages and can aid in the quantitative comparison of the proposed design with respect to any other geometry. To corroborate the simulation results, the local current density is also estimated experimentally by designing a local current density measurement device. The novelty of the device lies in the fact that its functionality has been accomplished within a thin multi-layered PCB. It does not require segmentation of any component of the fuel cell, is easy to incorporate in a stack; moreover, it is cost-effective. This part of the work is important in providing a better experimental validation of performance compared to the conventional current-voltage characteristics while studying a new flow field design.

\section{Computational Model}

\subsection{Description of geometry}


For the present investigation, an electrode area of $46 \mathrm{~cm}^{2}$ is considered with GDL area of $49 \mathrm{~cm}^{2}$. The complete geometrical model of single HT-PEFC is shown in Fig. 1a. Considering the nature of the electrode, a 5 channel, 6 turn configuration was chosen for the serpentine flow; spanning the entire electrode along with the active area within as shown in Fig. 1b. The cross-section of each channel is $1 \mathrm{~mm}^{2}$ and adjacent channels are spaced with ribs of $1 \mathrm{~mm}$ thickness. The gas diffusion layer thickness is chosen as $0.3 \mathrm{~mm}$.

\subsection{Conservation Equations}

A non-conservative form of the conservation equation is implemented in the present numerical simulations. Due to the assumption of steady state, incompressible flow, the continuity equation for flow in the channels can be written as [40]:

$\bar{\nabla} \cdot \overline{\mathrm{u}}=0$

The reactant flow in the channel is governed by Navier-Stokes equation, which is further simplified by neglecting the volume forces as shown in Eq. 2 [40].

$\bar{\nabla} \cdot(\rho \bar{u} \bar{u})=\mu \nabla^{2} \bar{u}-\bar{\nabla} P$

In the gas diffusion layer, the fluid velocities are proportional to the pressure drop and can be modelled based on Darcy's equation [41]:

$\overline{\mathrm{u}}=-\frac{\alpha}{\mu} \bar{\nabla} \mathrm{P}$

There are various aspects of heat transfer that is to be accounted while an HT-PEFC. There is convective heat transfer between the reactant gas streams and the solid components and conduction of heat between the different adjacent solid components as given by Eq. 4 [40]. Simultaneously, there is heat generation in different regions due to the reactions and other 
irreversible losses which are accounted in Eq. 5. In the current work, the generation of heat within bipolar plate is neglected, as its electrical and thermal conductivity is high enough compared to other components. The viscous heating is also ignored for modelling. Hence, the energy conservation can be represented as,

$\bar{\nabla} \cdot\left(\rho \mathrm{C}_{\mathrm{p}} \overline{\mathrm{u}} \mathrm{T}\right)=\bar{\nabla} \cdot\left(\mathrm{k}_{\mathrm{eff}} \bar{\nabla} \mathrm{T}\right)+\mathrm{S}_{\mathrm{T}}$

Where, $S_{\mathrm{T}}$ is the energy source term and given by,

$S_{T}=J_{v}\left(\frac{T \Delta S}{n F}+\eta_{\text {act }}\right)+J_{C}^{2}\left(\frac{R_{\text {mem }}}{t_{\text {mem }}}+\frac{R_{\text {con }}}{t_{\text {con }}}\right)$

Where,

$\mathrm{J}_{\mathrm{V}}=\frac{\mathrm{J}_{\mathrm{C}}}{\mathrm{t}_{\text {electrode }}}$

The mass fraction of the species is obtained by solving the convection-diffusion equation. For the $\mathrm{i}^{\text {th }}$ species, the conservation equation can be written as follows [42]:

$\bar{\nabla} \cdot\left(\rho \bar{u} Y_{i}\right)=\bar{\nabla} \cdot\left(\rho D_{i}{ }^{e f f} \bar{\nabla} Y_{i}\right)+S_{i}$

The effective diffusivity value $D_{i}{ }^{\text {eff }}$ in the porous zone is estimated from the porosity value $\epsilon$ using Eq. 8 [43].

$D_{i}{ }^{e f f}=D_{i} \epsilon^{1.5}$

Here, $D_{i}{ }^{\text {eff }}$ is the effective diffusivity of the $i^{\text {th }}$ species, which is determined using the dilute approximation theory (Fick's equation) [43]. The source for species creation and consumption has been denoted by $S_{\mathrm{i}}$. The source term can be computed from the value of local current as [44], 
$S_{i}= \pm \frac{J_{v} M_{i}}{n F}$

The Tafel approximation to the Butler-Volmer equation is used for estimating the local overpotential from the local current density in the catalyst surface [32].

$\eta_{\text {act }, \mathrm{c}}=\frac{\mathrm{RT}}{\alpha_{\mathrm{k}} \mathrm{F}} \ln \left(\frac{\mathrm{C}_{\mathrm{O}_{2}}^{\mathrm{ref}}}{\mathrm{C}_{\mathrm{O}_{2}}} \frac{\mathrm{J}_{\mathrm{c}}}{\mathrm{I}_{\mathrm{c}, \mathrm{T}}}\right)$

Where,

$\mathrm{J}_{\mathrm{C}, \mathrm{T}}=\mathrm{J}_{0, \text { ref }} \exp \left\{-\frac{\mathrm{E}_{\mathrm{A}}}{\mathrm{R}}\left(\frac{1}{\mathrm{~T}}-\frac{1}{\mathrm{~T}_{\mathrm{ref}}}\right)\right\}$

Here, $\mathrm{J}_{\mathrm{o}, \mathrm{ref}}$ is the exchange current density which indicates the reaction rate. It depends on upon the catalyst used for the electrode and the type of reaction. In the case of fuel cells, the value of the exchange current density for hydrogen oxidation is several orders higher than that of oxygen reduction.

At operating voltages close to open circuit voltage, the linear approximation has been used to estimate the activation overpotential.

The local current density is deduced from the operating voltage by the following relation [44]:

$\mathrm{J}_{\mathrm{C}}=\left(\frac{\mathrm{V}_{\mathrm{OC}}-\mathrm{V}_{\mathrm{OP}}-\eta_{\mathrm{act}, \mathrm{c}}}{\mathrm{R}_{\mathrm{tot}}}\right)$

Where, $\mathrm{R}_{\mathrm{tot}}$ is the total internal resistance arising from the ionic and electronic contribution which given by,

$\mathrm{R}_{\text {tot }}=\mathrm{R}_{\text {mem }}+\mathrm{R}_{\text {con }}$ 
The resistivity of the phosphoric acid-doped membrane strongly depends on the operating temperature and it is given by the following correlation, which is valid in the region 110 to 180 ${ }^{\circ} \mathrm{C}$.

$\mathrm{R}_{\text {mem }}(\mathrm{T})=\mathrm{R}_{1} \mathrm{~T}-\mathrm{R}_{2}$

Where $\mathrm{T}$ is the operating temperature of the HT-PEFC.

The values of $R_{1}$ and $R_{2}$ are summarized in Table 1 along with some of the other relevant parameters.

\subsection{Boundary Conditions}

The inlet mass flow rate boundary condition is applied at the inlets and is calculated using eq. 15 [44].

$\dot{\mathrm{m}}=\frac{\mathrm{IC, \text {avg }} \cdot \mathrm{A}_{\text {electrode }} \cdot \lambda \cdot \mathrm{MW}_{\mathrm{O}_{2}}}{4 \mathrm{~F}}$

Here, $\mathrm{J}_{\mathrm{C}, \mathrm{avg}}$ is the average cathodic cell current density which is drawn from the cell at a particular operating voltage. The parameter $A_{\text {electrode, }}$ refers to the cell active area, $\lambda$ is the stoichiometry factor and $\mathrm{MW}_{\mathrm{O}_{2}}$ is the molecular mass of oxygen. The temperature of inlet fluid is specified as room temperature. At the outlet side, a pressure outlet type boundary condition is set and the value is specified to be at atmospheric pressure. The flow field external wall temperatures are kept constant at $160^{\circ} \mathrm{C}$ and the remaining boundary surfaces are specified as adiabatic. 


\subsection{Computational Procedure}

The geometry creation and meshing have been performed using Ansys Workbench version 14.5. During meshing, the hexahedral submap scheme was adopted to generate quad type mesh in all the geometrical domains. Grid independence has been carried out both with respect to pressure drop in the channel and current density as the parameter. The mesh found suitable from grid refinement study has 942678 cells, which was then imported in the solver (Ansys Fluent). Subsequently, the boundary conditions are set on the respective surfaces and the solution is initialized. Under-relaxation is used in the solution for the stability of the species and energy conservation equations. This is achieved by setting the value of 0.5 for the species and 0.5 for the energy term in the beginning. In due course of the solution, these values are increased depending upon the nature of the solution. Moreover, limits have been placed on values of the activation overpotential so that it remains physically sensible. The solution is started by choosing the operating voltage of the fuel cell. At the next step, local overpotential value is assumed and local current density is calculated from the guessed value of overpotential. The sum of the current density across the active area is calculated and an equivalent flow rate which can maintain the current density is set at the inlet. The governing equations consisting of the mass, momentum and energy are solved using the SIMPLE algorithm. Subsequently, the species equation is solved and the mass fraction of the species are obtained across the active area. Based on the species concentration, the local overpotential values, and local current density is updated. The solution is iteratively calculated till the local overpotential between two subsequent iterations matches with chosen termination criteria (10e-04 for overpotential and $10^{-06}$ for the residuals of other parameters). The hardware for carrying out the solution consists of an Intel iCore(TM) i7-2600 processor at $3.4 \mathrm{GHz}$ and $16 \mathrm{~GB}$ RAM. 


\subsection{Assumptions}

The validation of the numerical predictions can only be confirmed by similar experimental findings. As shown in Fig. 2, the experimental set-up consists primarily of the HT-PEFC equipped with membrane electrode assembly, commercially known as Dapozol G77 from Danish Power Systems. In this case, according to specifications, the actual active area of the electrode of $6.8 \mathrm{~cm} \mathrm{X} 6.8 \mathrm{~cm}$ is considered. The gas diffusion layer area is slightly larger with an area of 7 $\mathrm{cm}$ X $7 \mathrm{~cm}$. Along with the membrane electrode assembly; the HT-PEFC set-up consists of modified serpentine flow-field for anode and cathode, current collectors and end plates. A segmented, multi-layered Printed Circuit Board (PCB) based on in-house design was fabricated and introduced between the cathode bipolar and the endplate. This device measures the local current density and will be henceforth referred as the Current Distribution Mapping Device (CDMD). The surface of the segmented side of the CDMD is in contact with the cathode BPP which allows current localized current collection across the plane of the fuel cell. In the middle, a number of in-plane resistors $(20 \mathrm{~m} \Omega$ resistance at room temperature $)$ are arranged in contact with the segments. The electric current collected from each segment flows through the resistances and the potential drop across it is measured by a data logger. The other surface of the CDMD unites the current from the individual resistors before it flows through the endplates. Precaution has also been exercised to ensure that the surface of the current collectors and the opposite side which makes contact with the endplate are polished. This aids in reducing any loss due to contact resistance amongst the cell components. The resistance of the CDMD is calibrated with respect to temperature by passing a total current of 3 A. This reduces the error in accuracy which may arise due to any change in the temperature of the resistors during measurement. The calibration is immediately repeated after local current density measurements are made. An area-weighted 
uniformity index (UI) is defined in eq. 16 to compare different current density distribution. $\mathrm{UI}=1-\frac{\sum_{\mathrm{k}=1}^{\mathrm{n}}\left(\left|\mathrm{J}_{\mathrm{C}}^{\mathrm{k}}-\mathrm{J}_{\mathrm{C}, \text { avg }}\right|\right) \cdot \mathrm{A}_{\mathrm{seg}}}{\mathrm{J}_{\mathrm{C}, \mathrm{avg}} \cdot \mathrm{A}_{\text {electrode }}} \quad 16$

Where, $\mathrm{J}_{\mathrm{C} \text {,avg }}$ is experimental average current density, $\mathrm{J}_{\mathrm{C}}^{\mathrm{k}}$ is local current density in a particular segment, k possessing an area $A_{\text {seg. }}$.

Uniformity index provides a quantitative comparison of different current density distribution. Higher values of the UI indicate a current density distributions which offer better homogeneity. The data from each segment of the CDMD is measured and stored during a particular measurement interval in a Datalogger of make Graphtec GL800. The fuel/oxidant flowrate, temperature control and electrical load are maintained by a Greenlight fuel fell test station.

\section{$4 \quad$ Results and Discussions}

During experimental study, the temperature of the cell is maintained at $160{ }^{\circ} \mathrm{C}$ and reactant flow rate is controlled on the anode and cathode to maintain stoichiometry of 2.5 . The polarisation behaviors of the single cell obtained from the simulation as well as an experiment are depicted in Fig. 3. The simulated polarisation curve is obtained with and without the consideration of interfacial contact resistance. Comparing polarisation curves in the Fig. 3, it is observed that the inclusion of contact resistance in the model is able to predict the performance more accurately. The slope of the curve (1) (in ohmic regime) is higher by a factor of $18 \%$, compared to the simulated curve $(2 \mathrm{a})$.

The current density distribution is simulated for different mean current densities using the CFD model. The current density distribution profile obtained from the simulation, for an average current density of $0.15 \mathrm{~A} \mathrm{~cm}^{-2}$ is shown in Fig. 4a. The current density distribution over the 
electrode area varies between $\sim 0.08 \mathrm{~A} \mathrm{~cm}^{-2}$ and $0.2 \mathrm{~A} \mathrm{~cm}^{-2}$, however, a major portion of the active area has current density lying in the range of 0.14 to $0.16 \mathrm{~A} \mathrm{~cm}^{-2}$ with a UI value of 0.989 . Current density distribution profile for an average current density of $0.52 \mathrm{~A} \mathrm{~cm}^{-2}$ is being shown in Fig. 4b. The UI calculated for the distribution is 0.986 and a large part of the active area is found to exhibit local current density in the range from 0.52 to $0.54 \mathrm{~A} \mathrm{~cm}^{-2}$. This indicates that the spatial uniformity in the performance of the cell is maintained even at higher current densities with proposed flow field.

In addition to the experimental validation of the polarisation curve, the current density distribution on the electrode area is validated with the experimental results as shown in Fig. 5. The current density distribution (CDD) on the electrode surface at an average current density of $0.4 \mathrm{~A} \mathrm{~cm}^{-2}$, obtained from the CDMD is plotted in Fig. 5a. The simulated CDDs for same average current density are also plotted as a surface map by sub-dividing the electrode surface into 36 segments and averaging out the data in each segment in Fig. 5b. In the figure, the inlet can be identified at the top right corner and the exit from the diagonally opposite corner. During modelling, the in-plane transport of the charges in the electrode and GDL are neglected. Though, this will not affect the overall polarisation behaviour as it gives the area-averaged value of current density obtained at the electrode-GDL interface. In other terms, the current generated at the electrode also undergoes some redistribution while passing across the GDL. This aspect of local current distribution would also elude present methods of experimental measurement as the channel and ribs are of $1 \mathrm{~mm}$ dimension. Present CDMD have segments with capture areas of the dimension of $\sim 1 \mathrm{~cm}^{2}$, which is inadequate to capture this behaviour. The mismatch in percent between simulation and experimental results is shown in Fig. 5c. The UI value for the experimental case is 0.982 while for the simulated result, it is 0.985 . The high UI means that 
major portion of the cell active area has values close to the average current density. Only the inlet and outlet regions have a noticeable departure. The standard deviation of the plotted values in the case of experimental data has a value of $0.016 \mathrm{~A} \mathrm{~cm}^{-2}$. In the case of the simulated results, the standard deviation of the values is $0.012 \mathrm{~A} \mathrm{~cm}^{-2}$. The maximum deviation between the two profiles is $\sim 6 \%$.

The repeating local gradients in the simulation results can be co-related with the number of channels used for the flow field. In the compensated serpentine design, the number of channels is varied and simulated for 2 and 3 channels under similar operating conditions. The variation in the current density distribution for different channels is plotted in Fig. 6. The difference in average current density with 2 and 3 channels is insignificant, however, it is seen from the Fig. 6 that lower channel numbers show a higher gradient in local current density and leads to a lower uniformity index. The uniformity index is noted to be 0.986 for 3 channels and 0.985 for 2 channels.

In Fig 7, a performance comparison between conventional serpentine with the proposed compensated serpentine flow field is carried out based on CFD simulation under constant voltage mode. The polarisation curve justifies that performance is improved for the modified design under operation at similar conditions. At $0.57 \mathrm{~V}$, the serpentine design performed with a power density of $0.18 \mathrm{~W} \mathrm{~cm}^{-2}$ whereas, the compensated serpentine depicts a power density of $0.22 \mathrm{~W}$ $\mathrm{cm}^{-2}$ leading to an improvement in the performance of $\sim 22 \%$. The pressure drop for compensated serpentine was found to be $\sim 0.51 \mathrm{kPa}$ at a flow rate of $0.59 \mathrm{lpm}$, which was found to be marginally higher than the serpentine, under similar conditions. In Fig 8, the spatial performance is compared between the two designs at an operating voltage of $0.57 \mathrm{~V}$. There are some repeating gradients of current density which pertain to the number of channels used for the 
proposed flow field. Due to higher homogeneity in current density distribution, a higher average current density of $0.39 \mathrm{~A} \mathrm{~cm}^{-2}$ is obtained for the proposed flow field compensated serpentine geometry. Under similar conditions, the average current density is $0.32 \mathrm{~A} \mathrm{~cm}^{-2}$ for serpentine geometry. The gradient in local current density from the inlet to the outlet along the channel flow path, which is noticeable in the case of serpentine and it lies in the ranges, $240 \mathrm{~mA} \mathrm{~cm}{ }^{-2}-380$ $\mathrm{mA} \mathrm{cm}{ }^{-2}$ Whereas, in the case of compensated serpentine it lies in the ranges $320 \mathrm{~mA} \mathrm{~cm}{ }^{-2}-436$ $\mathrm{mA} \mathrm{cm}{ }^{-2}$. The area averaged uniformity index for the compensated serpentine geometry is 0.985 , whereas, for the serpentine geometry, it is 0.96 .

\section{Conclusions}

A new flow field geometry is proposed in present work and its performance is demonstrated with both experimental and simulated results for an HT-PEFC. The proposed geometry is intended as an alternative to serpentine flow field, especially when better current density distribution is the requirement in the fuel cells. In order to demonstrate the capability of the design, a threedimensional CFD based simulation have been carried out. The simulation methodology was successful in simulating a lab scale cell of active area $49 \mathrm{~cm}^{2}$ with the available computational resource. The simulation result demonstrates that a higher average current density (about $22 \%$ ) and better current density distribution (uniformity factor of 0.998) can be attained with compensated serpentine flow field in comparison to serpentine design (uniformity factor of 0.96 ) at the same operating voltage. The major improvement is observed in the middle section of the flow-field, while the inlet and outlet section show higher and lower current density values respectively, similar to serpentine flow fields. But, in serpentine flow fields, the current density gradient closely follows the channel length along each turn from the inlet to the outlet section. In modified serpentine, the result indicates that if two adjacent reactant channels have a difference 
in reactant concentration, then cross-diffusion of gases is possible. This leads to better current density homogeneity and also higher current density values. The advantage in current density uniformity means that the flow field design can be of importance when there is a constraint on the maximum current density and thermal gradient when the cell area is scaled up. The drawback of placing the channels in such fashion is a higher pressure drop compared to the serpentine flow field. The polarisation behaviour, as well as the current density distribution obtained from simulations, have been validated experimentally and a good agreement has been noted. In addition to validating the polarisation behaviour, the current density distribution is also mapped in experiments for an HT-PEFC for further confirmation of the improvements observed. For the current density distribution validation, a current density measurement device (CDMD) has been fabricated in the laboratory. The compactness of the CDMD allows the possibility of integration with both single cell and stacks without any component modification or expensive components. In our single cell set-up, the CDMD was able to measure the spatial current density of the operating cell with good accuracy. The local current density measurements have been in agreement with the simulated results with the maximum mismatch factor not exceeding $6 \%$. Additionally, there is low cost, ease of manufacture and design customization associated with the presented CDMD compared to current mapping devices available in the commercial market. 


\section{Acknowledgement}

The authors express their gratitude towards Prof. Nedjib Djilali, University of Victoria, Canada for his valuable inputs. Also author (DS) thank to the Department of Energy Technology, Aalborg University for funding related to travel and lab expenditures.

\section{References}

[1] A. Chandan, M. Hattenberger, A. El-kharouf, S. Du, A. Dhir, V. Self, B. G. Pollet, A. Ingram, and W. Bujalski, "High temperature (HT) polymer electrolyte membrane fuel cells (PEMFC) - A review," J. Power Sources, vol. 231, pp. 264-278, Jun. 2013.

[2] P. Krishnan, J.-S. Park, and C.-S. Kim, "Performance of a poly(2,5-benzimidazole) membrane based high temperature PEM fuel cell in the presence of carbon monoxide," $J$. Power Sources, vol. 159, no. 2, pp. 817-823, Sep. 2006.

[3] S. J. Andreasen, J. R. Vang, and S. K. Kær, "High temperature PEM fuel cell performance characterisation with $\mathrm{CO}$ and $\mathrm{CO}_{2}$ using electrochemical impedance spectroscopy," Int. J. Hydrogen Energy, vol. 36, no. 16, pp. 9815-9830, Aug. 2011.

[4] S. Authayanun, D. Saebea, Y. Patcharavorachot, and A. Arpornwichanop, "Effect of different fuel options on performance of high-temperature PEMFC (proton exchange membrane fuel cell) systems," Energy, vol. 68, pp. 989-997, Apr. 2014.

[5] S. J. Andreasen, S. K. Kær, and S. Sahlin, "Control and experimental characterization of a methanol reformer for a $350 \mathrm{~W}$ high temperature polymer electrolyte membrane fuel cell system," Int. J. Hydrogen Energy, vol. 38, no. 3, pp. 1676-1684, Feb. 2013.

[6] B. Najafi, A.-H. Mamaghani, "Long-term performance analysis of an HT-PEM fuel cell based micro-CHP system: Operational strategies," Appl Energy, vol. 147, pp. 282-292, Jun. 2015.

[7] R.-C. Samsun, J. Pasel, H. Janßen, W. Lehnert, R. Peters, D. Stolten, "Design and test of a $5 \mathrm{kWe}$ high-temperature polymer electrolyte fuel cell system operated with diesel and kerosene," Appl Energy, vol. 114, pp. 238-249, Feb. 2014.

[8] E. Romero-Pascual and J. Soler, "Modelling of an HTPEM-based micro-combined heat and power fuel cell system with methanol," Int. J. Hydrogen Energy, vol. 39, no. 8, pp. 4053-4059, Mar. 2014.

[9] N. Zuliani, R. Taccani, "Microcogeneration system based on HTPEM fuel cell fueled with natural gas: Performance analysis," Appl Energy, vol. 97, pp. 802-808, Sep. 2012. 
[10] Y. Wang, D. U. Sauer, S. Koehne, and A. Ersoez, "Dynamic modeling of high temperature PEM fuel cell start-up process," Int. J. Hydrogen Energy, vol. 39, no. 33, pp. 19067-19078, Nov. 2014.

[11] D. Singdeo, T. Dey, and P. C. Ghosh, "Modelling of start-up time for high temperature polymer electrolyte fuel cells," Energy, vol. 36, no. 10, pp. 6081-6089, 2011.

[12] C. Hartnig and T. J. Schmidt, "On a new degradation mode for high-temperature polymer electrolyte fuel cells: How bipolar plate degradation affects cell performance,"

Electrochim. Acta, vol. 56, no. 11, pp. 4237-4242, Apr. 2011.

[13] J.-R. Kim, J. S. Yi, and T.-W. Song, "Investigation of degradation mechanisms of a hightemperature polymer-electrolyte-membrane fuel cell stack by electrochemical impedance spectroscopy," J. Power Sources, vol. 220, pp. 54-64, Dec. 2012.

[14] A. Suzuki, Y. Oono, M. C. Williams, R. Miura, K. Inaba, N. Hatakeyama, H. Takaba, M. Hori, and A. Miyamoto, "Evaluation for sintering of electrocatalysts and its effect on voltage drops in high-temperature proton exchange membrane fuel cells (HT-PEMFC)," Int. J. Hydrogen Energy, vol. 37, no. 23, pp. 18272-18289, Dec. 2012.

[15] X. Li and I. Sabir, "Review of bipolar plates in PEM fuel cells: Flow field designs," Int. J. Hydrogen Energy, vol. 30, no. 4, pp. 359-371, Mar. 2005.

[16] J.-Y. Jang, C.-H. Cheng, W.-T. Liao, Y.-X. Huang, and Y.-C. Tsai, "Experimental and numerical study of proton exchange membrane fuel cell with spiral flow channels," Appl. Energy, vol. 99, pp. 67-79, Nov. 2012.

[17] F. Liu, M. Kvesic, K. Wippermann, U. Reimer, and W. Lehnert, "Effect of Spiral Flow Field Design on Performance and Durability of HT-PEFCs," J. Electrochem. Soc., vol. 160, no. 8, pp. F892-F897, Jun. 2013.

[18] A. Arvay, J. French, J.-C. Wang, X.-H. Peng, and A. M. Kannan, "Nature inspired flow field designs for proton exchange membrane fuel cell," Int. J. Hydrogen Energy, vol. 38, no. 9, pp. 3717-3726, Mar. 2013.

[19] Y. Tabe, T. Nasu, S. Morioka, and T. Chikahisa, "Performance characteristics and internal phenomena of polymer electrolyte membrane fuel cell with porous flow field," J. Power Sources, vol. 238, pp. 21-28, Sep. 2013.

[20] X.-D. Wang, Y.-X. Huang, C.-H. Cheng, J.-Y. Jang, D.-J. Lee, W.-M. Yan, and A. Su, "Flow field optimization for proton exchange membrane fuel cells with varying channel heights and widths," Electrochim. Acta, vol. 54, no. 23, pp. 5522-5530, Sep. 2009.

[21] A. P. Manso, F. F. Marzo, J. Barranco, X. Garikano, and M. Garmendia Mujika, "Influence of geometric parameters of the flow fields on the performance of a PEM fuel cell. A review," Int. J. Hydrogen Energy, vol. 37, no. 20, pp. 15256-15287, Oct. 2012. 
[22] W.-M. Yan, H.-C. Liu, C.-Y. Soong, F. Chen, and C. H. Cheng, "Numerical study on cell performance and local transport phenomena of PEM fuel cells with novel flow field designs," J. Power Sources, vol. 161, no. 2, pp. 907-919, Oct. 2006.

[23] J. M. Jackson, M. L. Hupert, and S. A. Soper, "Discrete geometry optimization for reducing flow non-uniformity, asymmetry, and parasitic minor loss pressure drops in Ztype configurations of fuel cells," J. Power Sources, vol. 269, pp. 274-283, Dec. 2014.

[24] J. Wang, "Theory and practice of flow field designs for fuel cell scaling-up: A critical review," Appl Energy, vol. 157, pp. 640-663, Nov. 2015.

[25] C.-Y. Jung, H.-S. Shim, S.-Man Koo, S.-H. Lee, S.-C. Yi, "Investigations of the temperature distribution in proton exchange membrane fuel cells," Appl Energy, vol. 93, pp. 733-741, Nov. 2012.

[26] Y. Qin, b, X. Li, K. Jiao, Q. Du, Y. Yin "Effective removal and transport of water in a PEM fuel cell flow channel having a hydrophilic plate," Appl Energy, vol. 113, pp. 116126, Jan. 2014.

[27] H.-C. Chiu, J.-H. Jang, W.-M. Yanc, H.-Y. Li, C.-C. Liao "A three-dimensional modeling of transport phenomena of proton exchange membrane fuel cells with various flow fields," Appl Energy, vol. 96, pp. 359-370, Aug. 2012.

[28] A. Su, Y. M. Ferng, and J. C. Shih, "CFD investigating the effects of different operating conditions on the performance and the characteristics of a high-temperature PEMFC," Energy, vol. 35, no. 1, pp. 16-27, Jan. 2010.

[29] H. Sun, C. Xie, H. Chen, S. Almheiri, "A numerical study on the effects of temperature and mass transfer in high temperature PEM fuel cells with ab-PBI membrane," Appl Energy, vol. 160, pp. 937-944, Dec. 2015.

[30] S. Thomas, A. Bates, S. Park, A-.K. Sahu, S.-C. Lee, B.-R. Son, J.-G. Kim, D.-H. Lee, "An experimental and simulation study of novel channel designs for open-cathode hightemperature polymer electrolyte membrane fuel cells," Appl Energy, vol. 165, pp. 765776, Mar. 2016.

[31] J. Lobato, P. Cañizares, M. A. Rodrigo, F. J. Pinar, E. Mena, and D. Úbeda, "Threedimensional model of a $50 \mathrm{~cm} 2$ high temperature PEM fuel cell. Study of the flow channel geometry influence," Int. J. Hydrogen Energy, vol. 35, no. 11, pp. 5510-5520, Jun. 2010.

[32] M. Kvesić, U. Reimer, D. Froning, L. Lüke, W. Lehnert, and D. Stolten, "3D modeling of a $200 \mathrm{~cm} 2$ HT-PEFC short stack," Int. J. Hydrogen Energy, vol. 37, no. 3, pp. 2430-2439, Feb. 2012.

[33] L. Lüke, H. Janßen, M. Kvesić, W. Lehnert, and D. Stolten, "Performance analysis of HTPEFC stacks,” Int. J. Hydrogen Energy, vol. 37, no. 11, pp. 9171-9181, Jun. 2012. 
[34] M. Kvesić, U. Reimer, D. Froning, L. Lüke, W. Lehnert, and D. Stolten, "3D modeling of an HT-PEFC stack using reformate gas," Int. J. Hydrogen Energy, vol. 37, no. 17, pp. 12438-12450, Sep. 2012.

[35] V. K. Krastev, G. Falcucci, E. Jannelli, M. Minutillo, and R. Cozzolino, “3D CFD modeling and experimental characterization of HT PEM fuel cells at different anode gas compositions," Int. J. Hydrogen Energy, vol. 39, no. 36, pp. 21663-21672, Dec. 2014.

[36] P. Chippar, K. Oh, D. Kim, T.-W. Hong, W. Kim, and H. Ju, "Coupled mechanical stress and multi-dimensional CFD analysis for high temperature proton exchange membrane fuel cells (HT-PEMFCs)," Int. J. Hydrogen Energy, vol. 38, no. 18, pp. 7715-7724, Jun. 2013.

[37] I. Alaefour, G. Karimi, K. Jiao, X. Li "Measurement of current distribution in a proton exchange membrane fuel cell with various flow arrangements - A parametric study," Appl Energy, vol. 93, pp. 80-89, Mar. 2012.

[38] L. C. Pérez, L. Brandão, J. M. Sousa, and A. Mendes, "Segmented polymer electrolyte membrane fuel cells-A review," Renew. Sustain. Energy Rev., vol. 15, no. 1, pp. 169185, Jan. 2011.

[39] C. Siegel, I. Buder, and A. Heinzel, "Sectional electrochemical impedance analysis of a high temperature polymer electrolyte membrane fuel cell with three types of flow fields," Electrochim. Acta, vol. 112, pp. 342-355, Dec. 2013.

[40] H.K. Versteeg, W Malalasekera, An Introduction to Computational Fluid Dynamics: The Finite Volume Method (2nd Edition), Chapter 2, Pearson Education Limited, England, 2007.

[41] M.S. Ismail, D. Borman, T, Damjanovic, D.B. Ingham, M. Pourkashanian, “On the throughplane permeability of microporous layer-coated gas diffusion layers used in proton exchange membrane fuel cells," Int. J. Hydrogen Energy, vol. 36, no. 16, pp. $10392-$ 10402, Aug. 2011.

[42] M. Hossain, S.Z. Islam, P. Pollard, "Investigation of species transport in a gas diffusion layer of a polymer electrolyte membrane fuel cell through two-phase modelling," Renewable energy, vol. 51, pp. 404 - 418, March 2013.

[43] F. Hashemi, S. Rowshanzamir, M. Rezakazemi, "CFD simulation of PEM fuel cell performance: Effect of straight and serpentine flow fields," Mathematical and Computer Modelling, vol 55, no. 3-4, pp. 1540 - 1557, Feb. 2012.

[44] R. O’Hayre, S-W. Cha, W. Colella, F. B. Prinz, . Fuel Cell Fundamentals, 2nd Edition. John Wiley and Sons, Inc, New York, 2009. 


\section{List of Figures:}

Fig. 1. (a) Schematic diagram of compete geometrical model of the fuel cells, (b) Top view of the geometry for proposed flow field (compensated serpentine), (c) Multi-layered PCB based current density measurement device

Fig. 2. Schematic diagram of the experimental set-up

Fig. 3. Polarisation characteristics for the single cell HT-PEFC at $160{ }^{\circ} \mathrm{C}$

Fig. 4. Current density distribution obtained from experiment using CDMD for an average current density of (a) $0.15 \mathrm{~A} \mathrm{~cm}^{-2}$ and (b) $0.52 \mathrm{~A} \mathrm{~cm}^{-2}$

Fig. 5. Current density distribution for operating average current density of $0.39 \mathrm{~A} \mathrm{~cm}^{-2}$ and 0.57 $\mathrm{V}$ obtained using (a) experiment, (b) simulation and (c) mismatch (\%)

Fig. 6. Influence of number of channels on the local current density at $0.57 \mathrm{~V}$

Fig. 7. Comparison between performance of proposed design and serpentine configuration based on polarisation characteristics

Fig. 8. Current density distribution $\left(\mathrm{A} \mathrm{cm}^{-2}\right)$ for compensated serpentine and conventional serpentine geometries

\section{List of Table}

Table 1: Model parameter used in present study 
Table 1: Model parameter used in present study

\begin{tabular}{ll}
\hline \multicolumn{1}{c}{ Parameter } & \multicolumn{1}{c}{ Value (Unit) } \\
\hline Molecular weight of oxygen & $\left.32, \mathrm{~kg} \mathrm{kmol}^{-1}\right)$ \\
Molecular weight of hydrogen & $2.016, \mathrm{~kg} \mathrm{kmol}^{-1}$ \\
Molecular weight of water & $18, \mathrm{~kg} \mathrm{kmol}^{-1}$ \\
Faraday's constant & $96485000, \mathrm{C} \mathrm{kmol}^{-1}$ \\
Reference concentration of oxygen & $0.0033, \mathrm{kmol} \mathrm{m}^{-3}$ \\
$\alpha_{\mathrm{k}}$ & 0.75 \\
Real gas constant & $8.314, \mathrm{~J} \mathrm{~K}^{-1} \mathrm{~mol}^{-1}$ \\
$\mathrm{R}_{1}$ & $-25 \times 10^{-8}, \Omega \mathrm{K}^{-1} \mathrm{~m}^{2}$ \\
$\mathrm{R}_{2}$ & $1.8656 \times 10^{-4}, \Omega \mathrm{m}^{2}$ \\
$\mathrm{R}_{\text {con }}(\mathrm{T})$ & $15 \times 10^{-7}, \Omega \mathrm{m}^{2}$ \\
$\mathrm{R}_{\mathrm{CDM}}(\mathrm{T})$ & $9 \times 10^{-6}, \Omega \mathrm{m}^{2}$ \\
$\mathrm{~J}_{\mathrm{O}, \text { ref }}$ & $1000, \mathrm{~A} \mathrm{~m}^{-2}$ \\
Porosity & 0.4 \\
Permeability & $10^{-12}, \mathrm{~m}^{2}$ \\
\hline
\end{tabular}



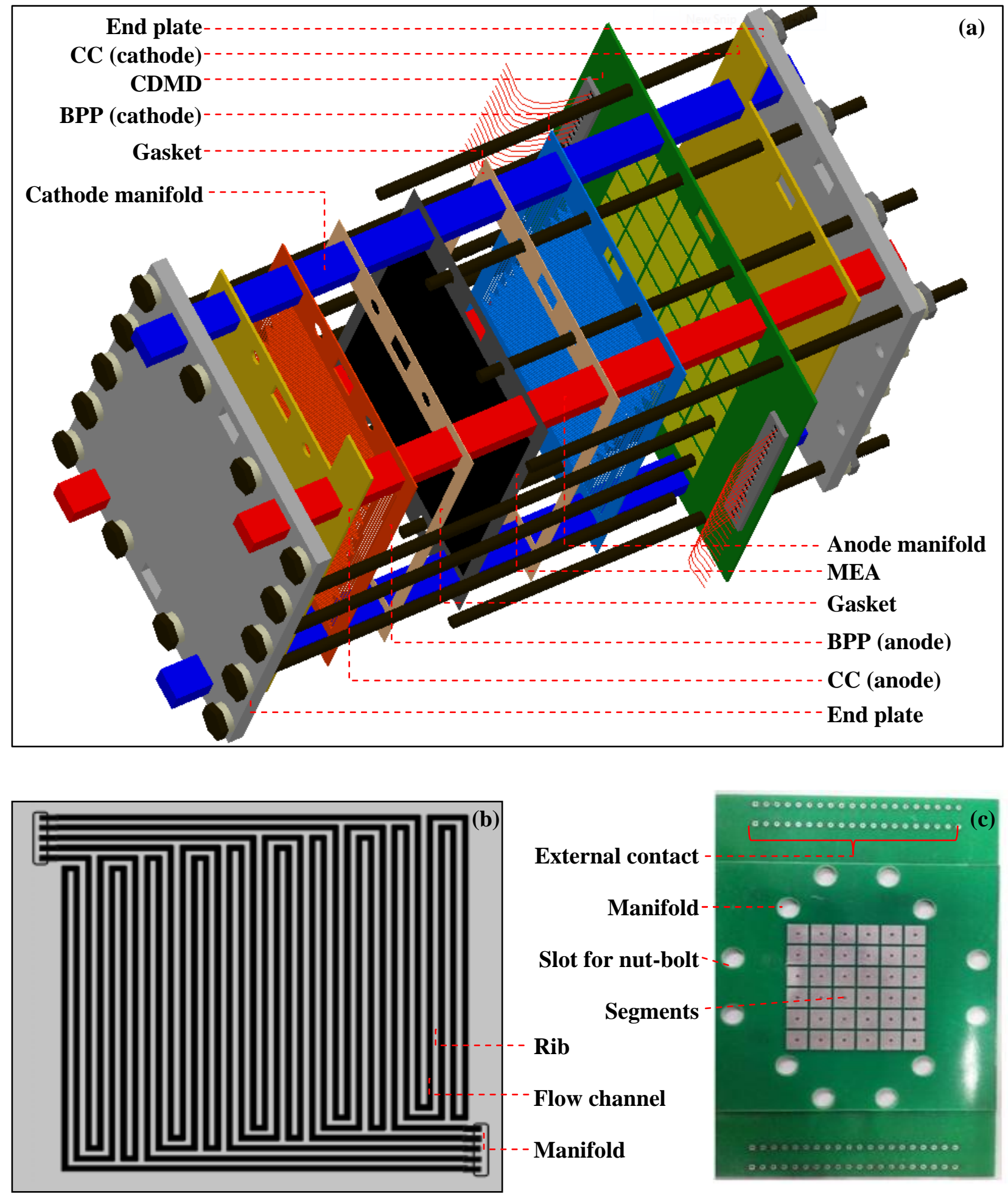

Fig. 1. (a) Schematic diagram of compete geometrical model of the fuel cells, (b) Top view of the geometry for proposed flow field (compensated serpentine), (c) Multi-layered PCB based current density measurement device 


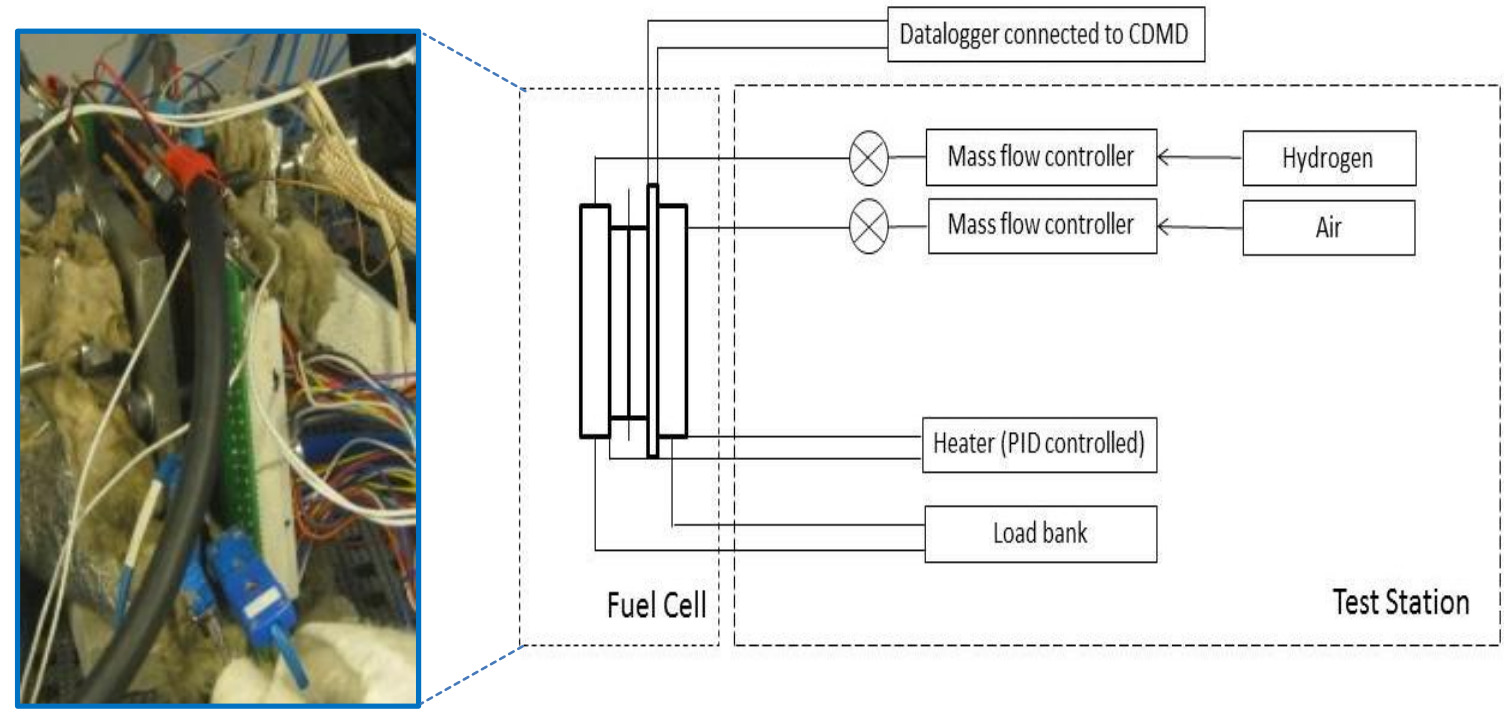

Fig. 2. Schematic diagram of the experimental set-up 


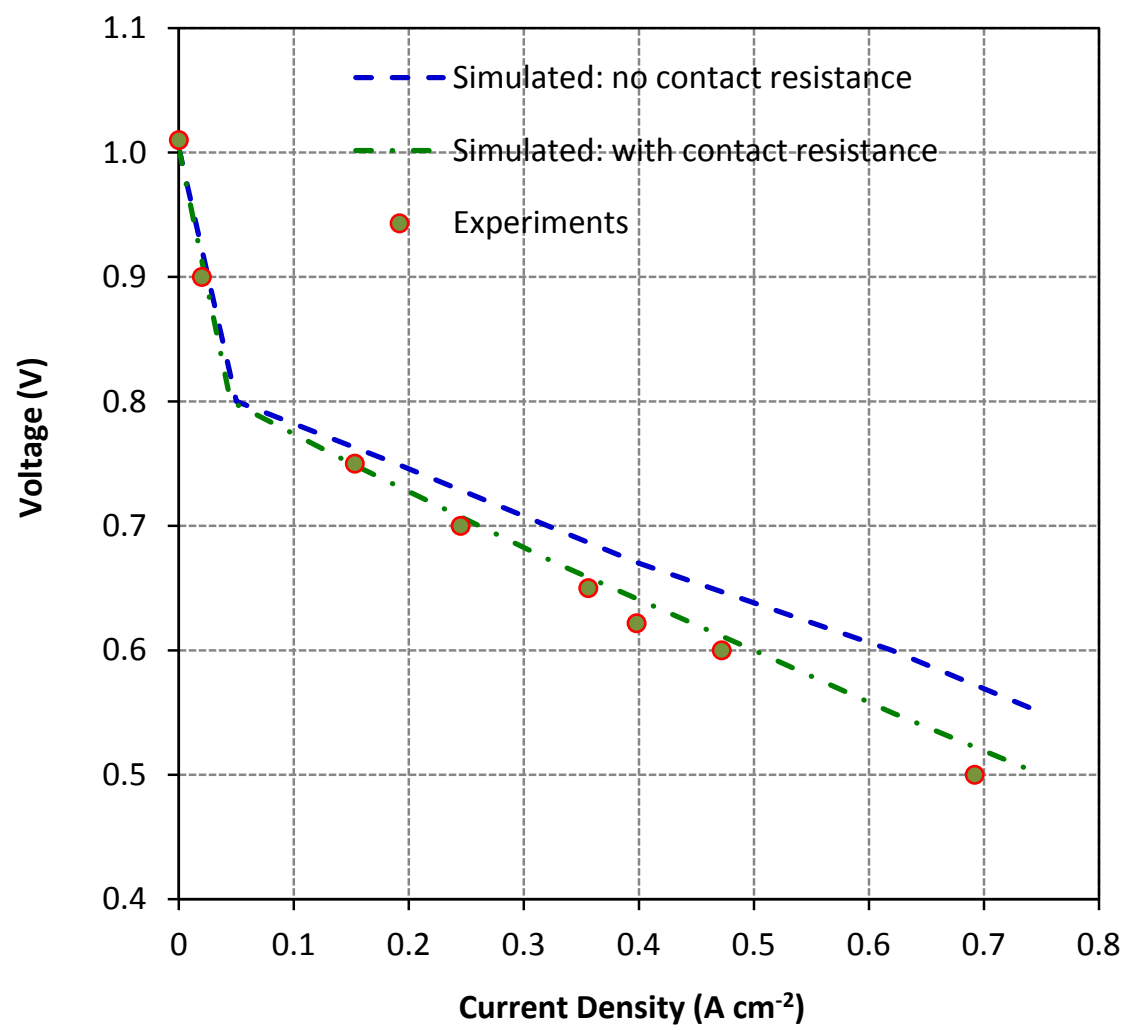

Fig. 3. Polarisation characteristics for the single cell HT-PEFC at $160{ }^{\circ} \mathrm{C}$ 

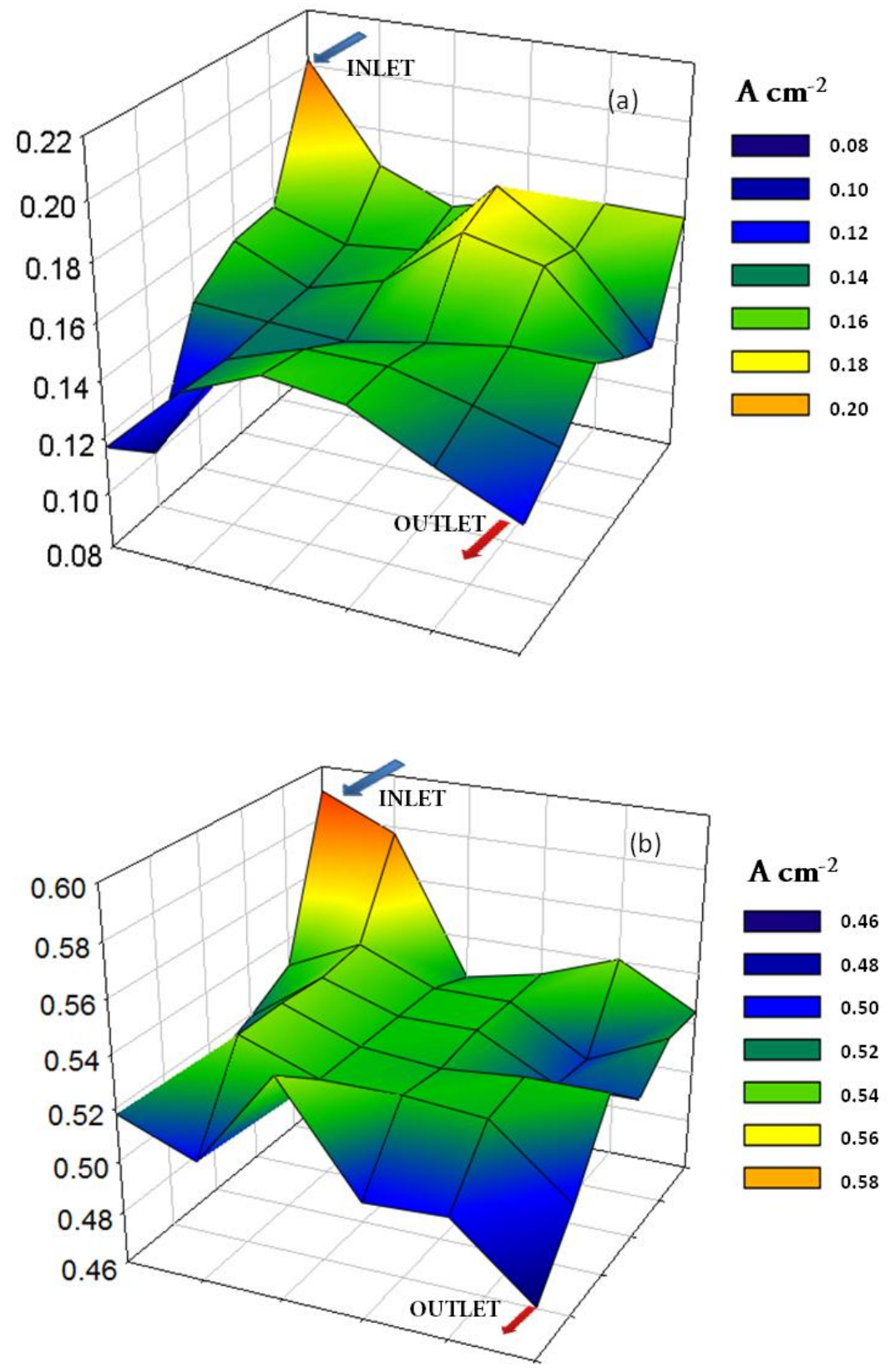

Fig. 4. Current density distribution obtained from experiment using CDMD for an average current density of (a) $0.15 \mathrm{~A} \mathrm{~cm}^{-2}$ and (b) $0.52 \mathrm{~A} \mathrm{~cm}^{-2}$ 

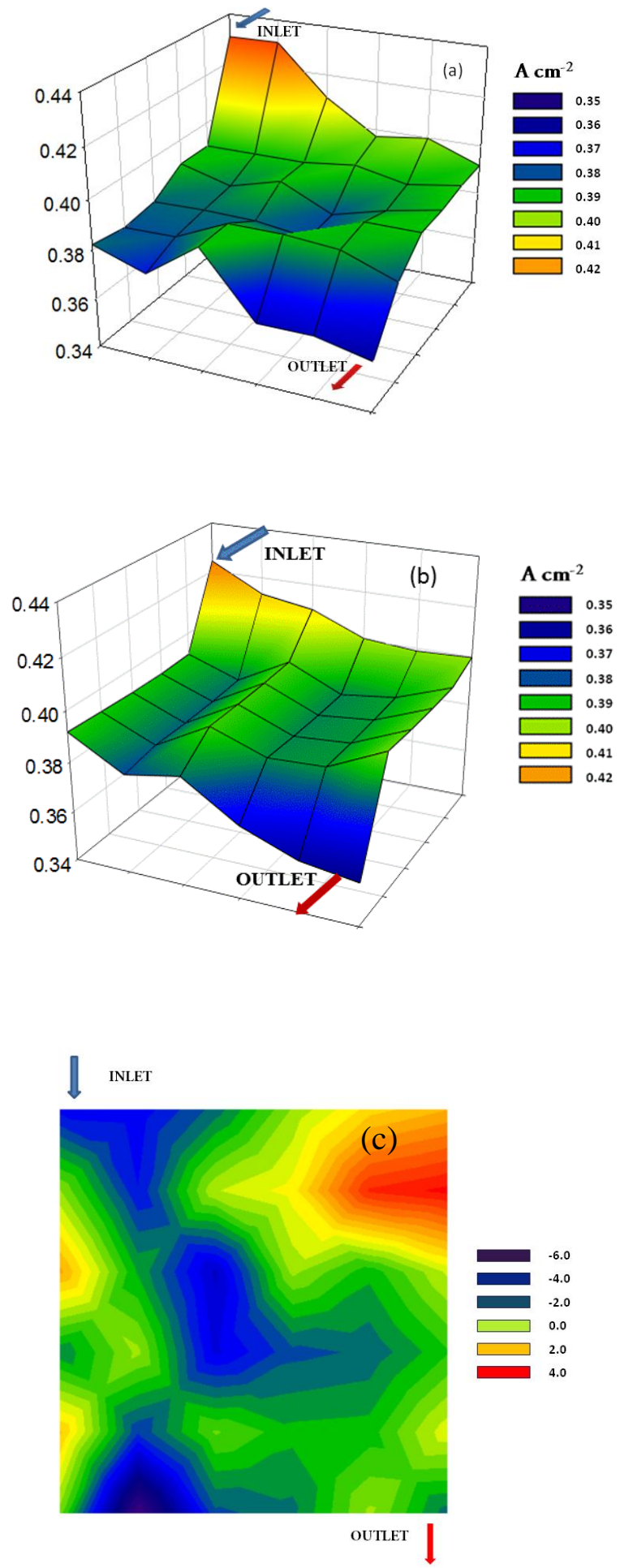

Fig. 5. Current density distribution for operating average current density of $0.39 \mathrm{~A} \mathrm{~cm}^{-2}$ and $0.57 \mathrm{~V}$ obtained using (a) experiment (b) simulation and (c) mismatch (\%) 

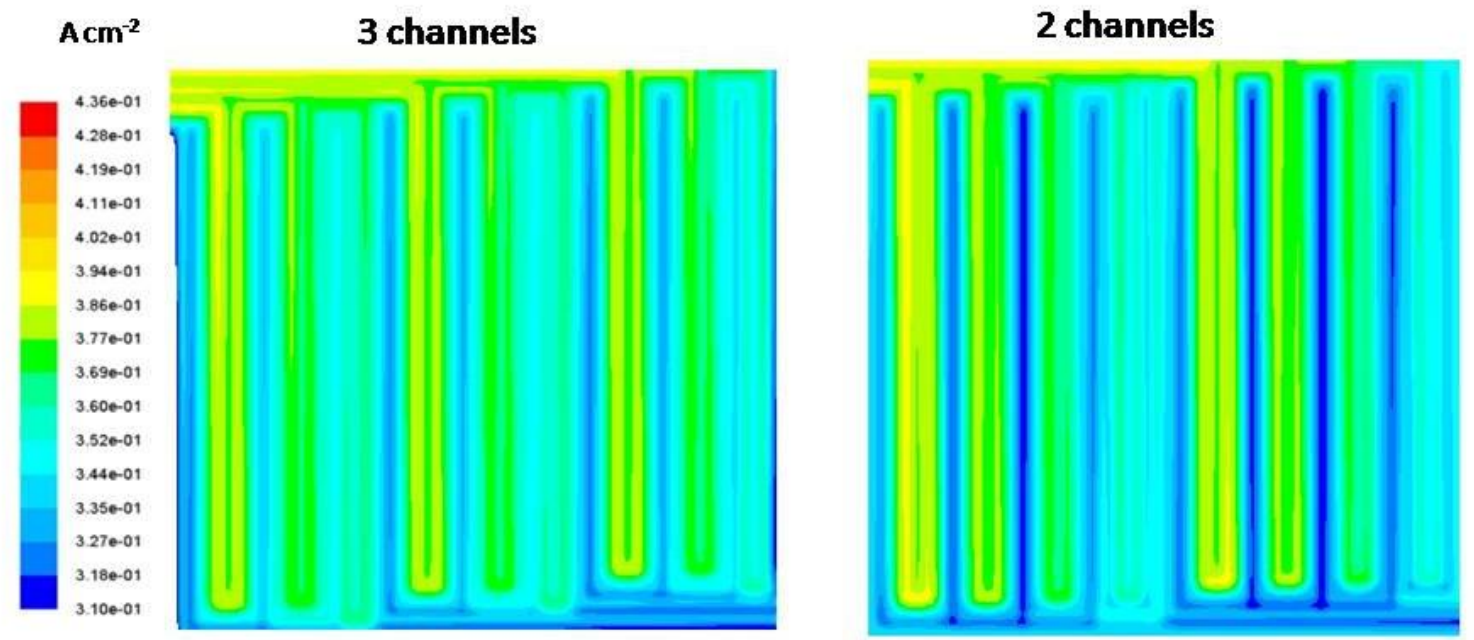

Fig. 6. Influence of number of channels on the local current density at $0.57 \mathrm{~V}$ 


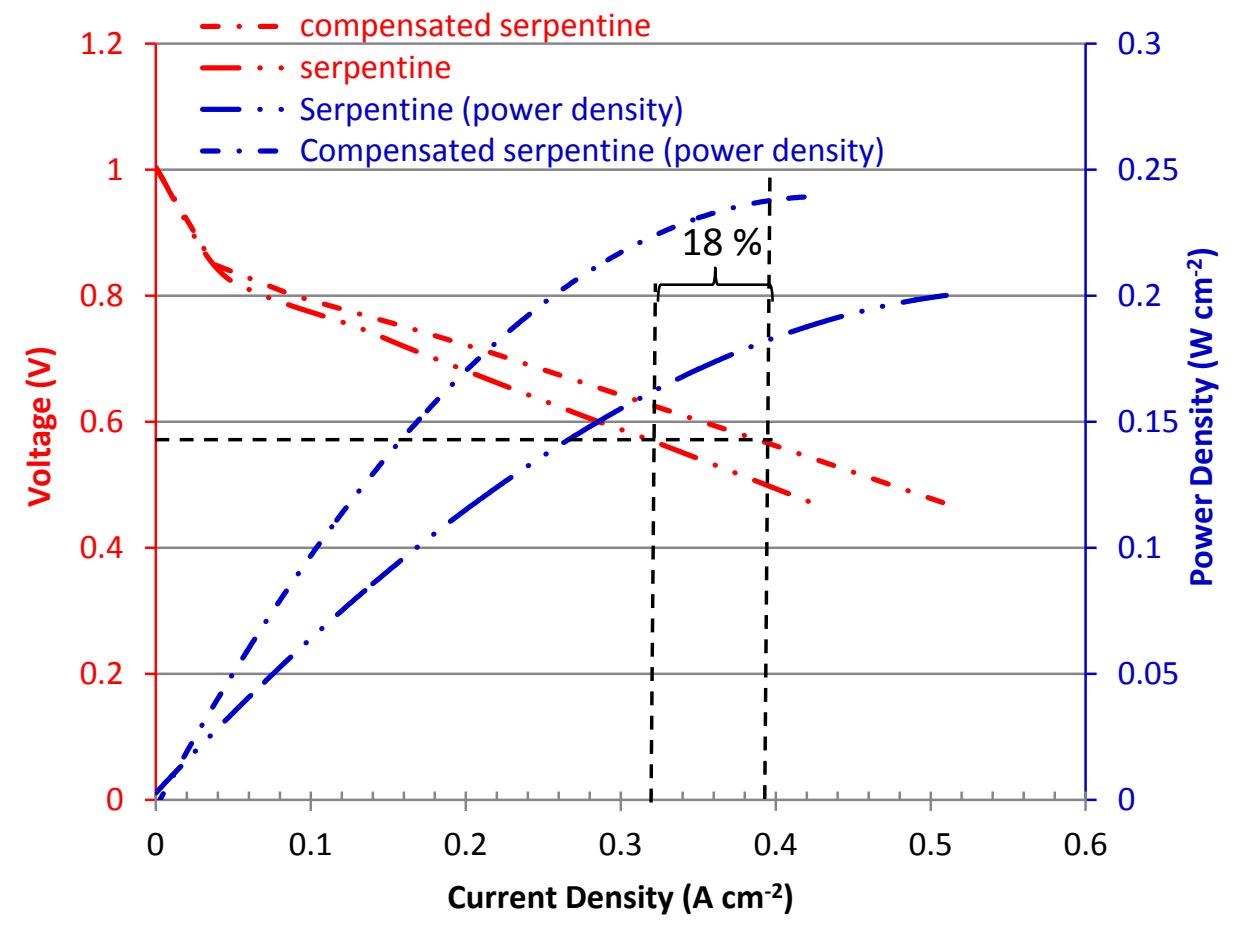

Fig. 7. Comparison between performance of proposed design and serpentine configuration based on polarization characteristics 

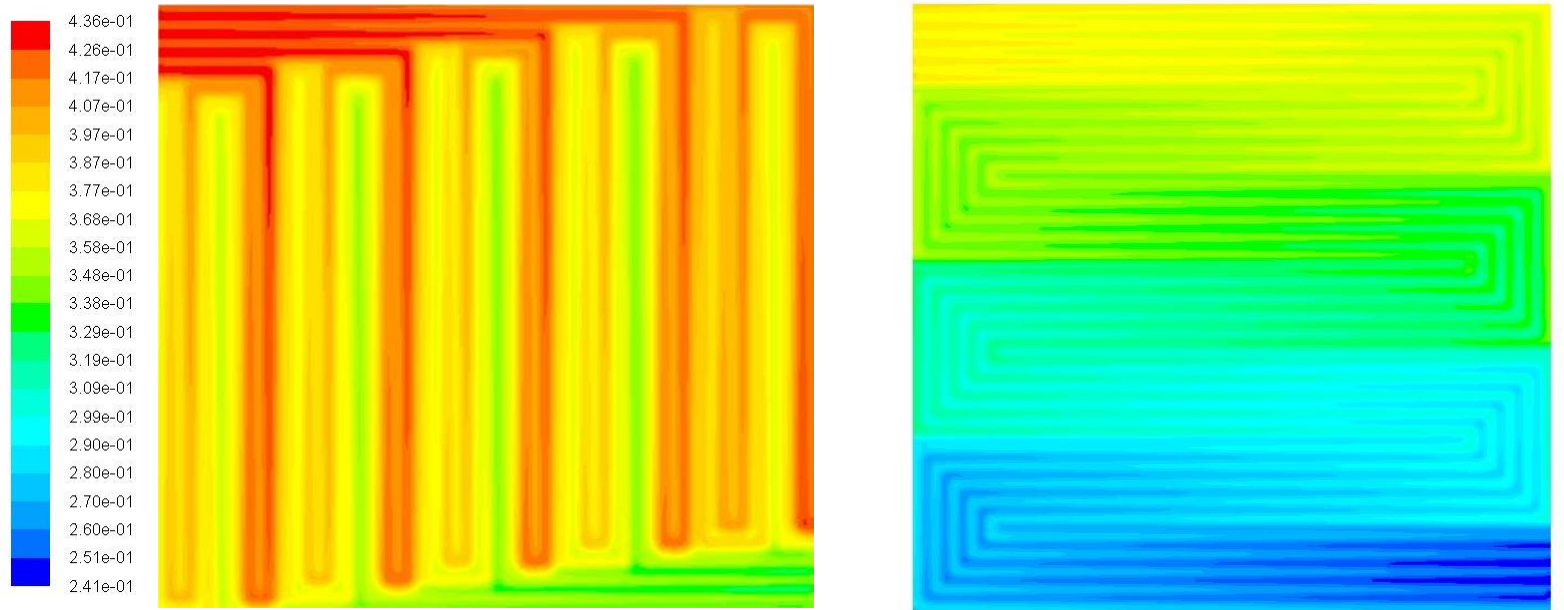

Fig. 8. Current density distribution $\left(\mathrm{A} \mathrm{cm}^{-2}\right)$ for compensated serpentine and conventional serpentine geometries 